\title{
Erratum to: Nottingham prognostic index plus (NPI+) predicts risk of distant metastases in primary breast cancer
}

\author{
Andrew R. Green ${ }^{1}$ D. Soria ${ }^{2}$ D. G. Powe ${ }^{3}$ C. C. Nolan ${ }^{1}$ M. Aleskandarany ${ }^{1}$ ' \\ M. A. Szász ${ }^{4}$ A. M. Tókés ${ }^{4}$ G. R. Ball ${ }^{5}$ J. M. Garibaldi ${ }^{2}$ E. A. Rakha ${ }^{1,3}$. \\ J. Kulka ${ }^{4}$ I. O. Ellis ${ }^{1,3}$
}

Published online: 22 July 2016

(C) Springer Science+Business Media New York 2016

\section{Erratum to: Breast Cancer Res Treat (2016) 157:65-75 \\ DOI 10.1007/s10549-016-3804-1}

Unfortunately, the original article was published under CC BY-NC license, which is not compliant with the author funder's OA policy. The article's correct licence is CC BY license and the correct open access statement is given below.
Open access: This article is distributed under the terms of the Creative Commons Attribution 4.0 International License (http://creativecommons.org/licenses/by/4.0/), which permits unrestricted use, distribution, and reproduction in any medium, provided you give appropriate credit to the original author(s) and the source, provide a link to the Creative Commons license, and indicate if changes were made.

The online version of the original article can be found under doi:10.1007/s10549-016-3804-1.

Andrew R. Green

andrew.green@nottingham.ac.uk

1 Division of Cancer and Stem Cells, School of Medicine, Breast Cancer Pathology Research Group, Academic Unit of Oncology, Nottingham City Hospital, University of Nottingham, Hucknall Road, Nottingham NG5 1PB, UK

2 Computer Science and Advanced Data Analysis Centre, University of Nottingham, Nottingham, UK

3 Cellular Pathology, Nottingham University Hospitals NHS Trust, Nottingham, UK

4 Second Department of Pathology, Semmelweis University, Budapest, Hungary

5 School of Science and Technology, College of Arts and Science, Nottingham Trent University, Nottingham, UK 